\title{
Privatisation of the Tole Tea Estate and the Brobon-Finex Saga: A Showcase of Corruption in a State Owned Corporation in Cameroon.
}

\author{
Clovis Ebot Obale* \\ Ph.D. Candidate, University of Yaounde I, Faculty of Arts, letters and Social Sciences, P.O. Box 755 Yaoundé, \\ Cameroon, Department of Geography, Cameroon \\ *Corresponding Author: Clovis Ebot Obale, Ph.D. Candidate, University of Yaounde I, Faculty of Arts, \\ letters and Social Sciences, P.O. Box 755 Yaoundé, Cameroon, Department of Geography, Cameroon
}

\begin{abstract}
The privatisation of the Tole Tea Estate has had negative consequences on the working conditions of workers. The magnitude of divestment proceeds and the complex nature of the transactions involved were enough grounds to attract corruption. The privatisation of the TTE created rents and unleashed processes that undermined anti-corruption policies in the company. The researcher employed a phenomenological research design with purposeful sampling of participants. Data collection entailed conducting in-depth interviews with 30 CTE workers alongside a documentary review of reports and technical documents on privatisation. The study asserts that the privatisation transactions of the TTE were marred by corruption. The former GM of the CDC undervalued the firm with the intension of selling it to his business associates (Brobon-Finex Plc.), a fake South African company at a giveaway price. Post-privatised TTE is now the scene of labour unrest and insecurity due to poor working conditions and little has been done by management to resolve the issue. The CTE management in a bid to protect her interest and avert court action have resorted to paying bribe to government officials. Furthermore, the study also affirms that privatisation and market liberalisation do not reduce corruption, contrary to the views of most neoliberals.
\end{abstract}

Keywords: Privatisation, Corruption, Brobon-Finex Plc, CTE, CDC, Tole Tea Estate, Cameroon.

\section{INTRODUCTION}

The World Economic Forum asserts that worldwide corruption costs about \$3.6 trillion annually.Corruption blooms in varied forms such as fraud, moneylaundering, cartels and bribing government officials. Corruption can be defined as the abuse of entrusted power for personal gains.It has the power to cripple governments and decimate economies (Jeffrey, 2014).Corruption has become a major international concern and the main topic on the agenda in most international conferences, policy forums and ministerial speeches. The rapid growth of corruption throughout the world is largely a result of increased privatisation of state owned enterprises worldwide with the support of western creditors and governments allowing multinational companies to operate with increased impunity. Furthermore, public enterprises are vulnerable to corruption due to their closeness to governments, politicians and public officials.Corrupt practices masterminded by multinationals undermine development and exacerbate inequality and poverty in developing countries. The anti-poverty and good governance agendas put forth by the IMF and World Bank to correct market deficiencies is ineffective to abate corruption in developing countries. Effective policies to fight against corruption in developing countries need to include sanctions against multinationals that engage in corrupt practices; increase political transparency, remove undue administrative bottle necks in a bid to speed up the privatisation transactions and also employ viable institutions and legal policies to guide the privatisation process (OECD, 2015).

The privatisation of the Tole tea estate was marred by corruption. The privatization transactions of the tea sector were masterminded by John Niba Ngu, the former General Manager of the CDC and Minister of Agriculture, a close friend of President Paul Biya. He employed his technical knowledge and connections within the regime in power to design the fake privatization of the Tole tea estates. Furthermore, althoughfinancial experts had estimated the value of these three tea estates at about FCFA 10 billion, John Niba Ngu and his collaborators finally sold the tea estates at FCFA 1.5 billion, 
less than the expected market price. In addition, in return for his loyal services to the CTE, the Board of Brobon Finex appointed John Niba Ngu as General Manager of the CTE on a salary and fringe benefits of about FCFA 4 milliona month. He was also allocated 5\% of the CTE's share capital, although this was later contested by the Board of Brobon Finex. There were also growing doubts about Brobon Finex's takeover when it became clear that the real owner of the CTE was Alhadji Baba Danpullo, a prominent politician and close friend of the president, who was using Brobon Finex as a shield. However, although he was not a signatory to the agreement between the government and Brobon Finex, he paid the money for the takeover of the Tole tea estates to the public treasury and has since then been fully engaged in other financial transactions on behalf of the CTE. Investigations carried out by the BLCC a year later in South Africa found that Brobon Finex existed in name only and had no office premises. Its chairman, Derrick Garvie, was indeed known in South African business circles but not in connection with Brobon Finex. These were enough evidences to justify the fact that Brobon Finex was merely a straw company(Konings, 2003).

\section{OBJECTIVES OF THE STUDY}

The study seeks to assess if corrupt practices were employed during the privatization negotiations of the Tole Tea Estate and its implications on the privatization outcome.

\section{REVIEW OF RELATED LITERATURE}

The Tole Tea Estate owes its creation to the desires of the colonial master's ambitions of exploiting the colonies for their economic interest. The main factors that favoured the location of this tea plantation at the foot of Mount Cameroon were influenced by the availability of land, labour and a favourable climatic condition. Tea was first experimented at the slopes of Mount Fako in 1928 when a tea nursery was first setup in the Botanic Garden in Limbe. This experimental farm was later followed by a Twenty-six hectares of light leafed and the dark-leafed Manipuri tea that were planted in Tole, still for experimental purposes. These tea species were imported from India by the Germans and proved suitable for cultivation at Tole (Konings, 2003). When colonial plantations were indigenized in 1947 following the creation of the CDC, the management of Tole tea estate were handed over to the new corporation. It can therefore be observed from the foregoing that the Tole tea estate was a structure that was inherited from colonialism. One of the key problems that confronted the colonial managers of this estate was the inability to secure labour around the plantation location. They had to move far away into the hinterlands to recruit labour in the grass fields of the West and North West Regions of the country (ibid).

Empirical studieson privatisation in most developing countries assert that privatisation of some state owned enterprises that were masterminded by the IMF and World Bank were marred by corruption leading to the undervaluing of the assets of these companies. Potential bidders are always willing to offer illegal payments to decision-makers who are instrumental in the privatisation negotiations in a bid to increase their chances of winning monopoly rents of these former state-owned enterprises.In addition, once these corrupt multinational companiesacquiresuch assets, they seek to protect these assets and avert court action or punishment by bribing government officials who are unpatriotic. This is a similar situation to what happened in the Tole tea estate and in other state owned enterprises in Cameroon that were privatised under the umbrella of the structural adjustment programme in the early $90 \mathrm{~s}$ and 2000s. It has become a common culture in most developing countries carrying out privatisation for rent-seekers to bribe public officials in exchange for favourable treatmentdue to poor institutions and legal frameworks existing in these countries (Rose-Ackerman, 2014).

Furthermore, qualitative literatures on corruption-inducing effects of privatization in sub-Saharan Africa, Asia and Europe now exist in most libraries and online platforms worldwide. In the former Soviet Union countries, somemanagers who were well connected to the governmentin power purchased several state owned enterprises at giveaway prices (Hellmann and Kaufmann, 2001). In sub-Saharan Africa where ethnic ties play an important role in politics, high-level state personnel'swere granted the leeway to manage the privatization process to their benefit. Public bureaucrats did everything to ensure that their loyal supporters benefited most in the privatisation process (Tangri and Mwenda, 2001). The lack of transparency in the privatization programmes in most developing countries in Africa enabled officials to accrue private benefits (Bennell, 1997). In 
most of these cases in Africa and Cameroon in particular, perpetrators of these corruption crimes were never prosecuted due to weak legal and institutional frameworks (Tangri and Mwenda, 2001).

The term corruption is a complex phenomenon making it difficult for any one theory to explain it all. One of the most widely adopted definitions of corruption includes rational choice assumptions and a principal-agent perspective that looks at corruption as the abuse of entrusted authority for personal gains (Svensson, 2005). Agents are delegated to carry out the provision of public goods on behalf of principals, although they fail to fulfil their duty to the principal. Agentsmore often try to realise their own preferences at the expense of the principal. Klitgaard's formula on corruption is in a better position to analyse the privatisation-corruption logicwhich adheres to rationalist principles: "Corruption $=$ monopoly + discretion - accountability". This is relevant in the public sector, where government authorities (agents) often enjoy monopoly and discretionary authority over state resources and decision-making functions. A lasting solution to such a situation is to reduce administrative monopoly powers through transparency, broaden authority through participation and also ensure accountability by enforcing sanctions for corrupt practices. Current anti-corruption measures in Cameroon largely mirror this logic (Klitgaard, 1988).

On the other hand, in the past the economic literature employed the use of the principal-agent model to analyse corruption, though recently scholars have resorted to use the collective action theory to explain the phenomenon. The collective action theory goes beyond traditional principal-agent ties and focus on the importance of trust and perception of individuals and their behaviour in society (Groenendijk, 1997). In addition, an institutional culture of corruption leads to the normalization of corrupt practices in society and at the level of individuals. In order to fight corruption, there is a need for collective action and coordinated approaches (Appolloni and Nshombo, 2014). Corruption is a negative practice that is deeply rooted in the Cameroonian society. It cuts across all sectors in the country ranging from the health sector, education, judiciary, financial, military, penitentiary, and telecommunication (Bechem, 2018). Cameroon has twice topped the chart of the most corrupt country in the world (1998 and 1999 respectively), according to the corruption perception index presented annually by Transparency International (Transparency International, 1998 \& 1999). However, although the government has intensified her efforts in the fight against corruption by putting in place institutions such as the National Anti-Corruption Commission and the Supreme State Audit, corruption still exist in all its forms in the country (Bechem, 2018).

\section{HYPOTHESIS}

$\mathrm{H}_{\mathrm{a}}$ : The privatization negotiations of the Tole Tea Estate were marred by corruption leading to the undervaluing of the company's assets.

$\mathrm{H}_{\mathrm{a}}$ : The privatisation of the Tole Tea Estate was not transparent since key stakeholders were not invited on the negotiating table (workers trade union and Bakweri elites).

$\mathrm{H}_{\mathrm{a}}$ : The privatisation of the Tole Tea Estate havehad negative consequences on the livelihood of workers particularly women who form more than $65 \%$ of the workforce.

\section{MAterials ANd Methods}

\subsection{Study Area}

The Tole Tea Estate is situated in Fako Division in the Sud-Ouest Region. Its geographical coordinates are $4^{\circ} 6^{\prime} 0^{\prime \prime}$ North and $9^{\circ} 13^{\prime} 0^{\prime \prime}$ East. It is situated on an undulating hill on the east facing side at the foot of mount Cameroon at an elevation of about 2000-2500 meters above sea level. The heavy rainfall in this area coupled with its high humidity and long dry season help to create a favourable environment for the growth of tea. The soils are heavily leached due to the heavy torrential rainfall making it poor in lime though rich in bases making it suitable for the growing of tea on mountain slopes. In 1928, the German planters introduced tea in Cameroon with an experimental tea farm of about 66 hectares at Tole.The creation of the CDC led to the handing over of former German plantations to this new corporation. The CDC got involved in tea management in 1954 when it took over the tea plantation at Tole (see map 5.1 below) (Bederman, 1968). The TTE became known as 
Privatisation of the Tole Tea Estate and the Brobon-Finex Saga: A Showcase of Corruption in a State Owned Corporation in Cameroon.

CTEfollowing its privatisation in2002 (see map 5.2 below). The inability of CDC to make profit led to its privatization in 2002 to the Cameroon Tea Estate (CTE). The CTE is made up of four tea estate; Ndawara, Tole, Ndu and Djuttitsa (Akara, 2006).

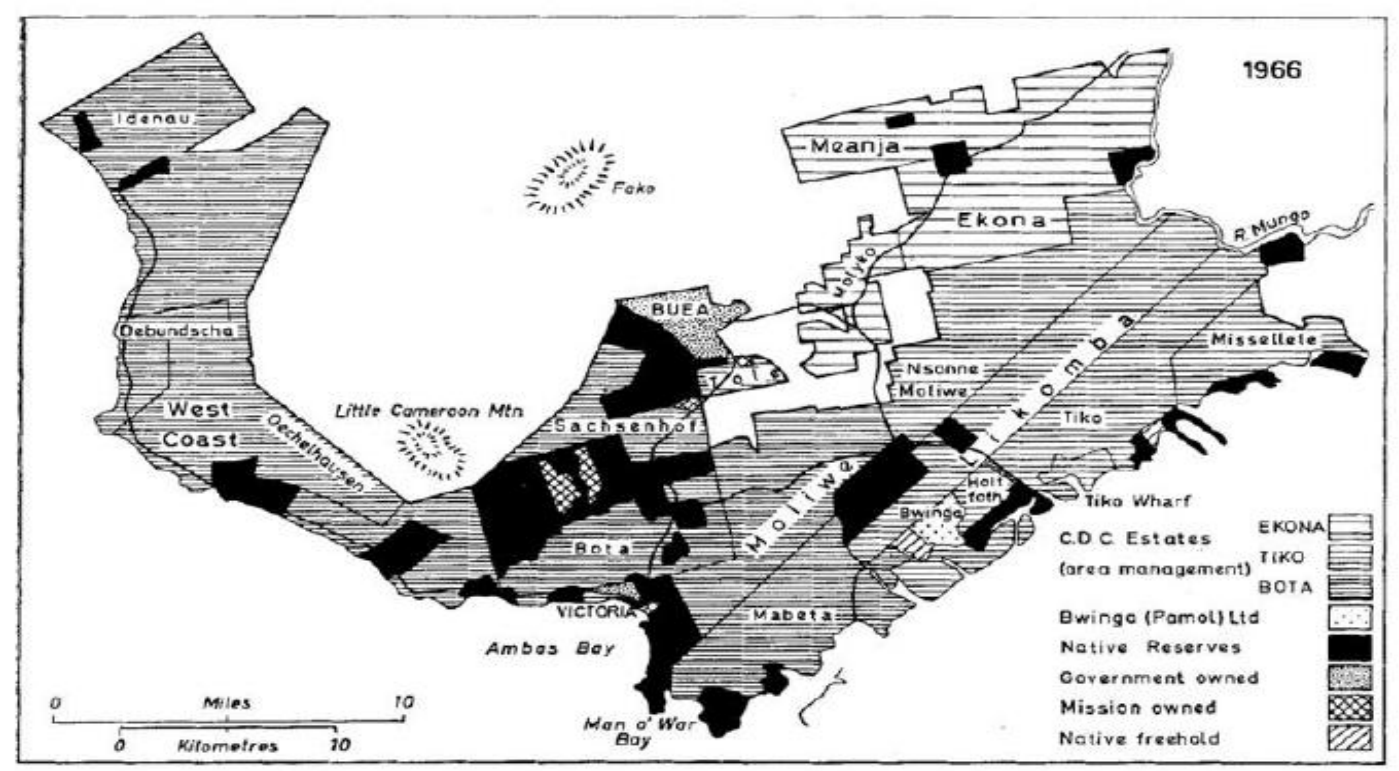

Fig. I: Plantations and Native Reserves. Victoria Division, West Cameroon - 1966. Almost all of the land on this map was alienated from the indigenous Bakweri by the Germans in the latter part of the Nineteenth Century. The Tole Tea Estate is now a part of the Cameroons Development Corporation and is located three miles from Buea.

Map5.1. A Map showing the Tole Tea Estate in 1966

Source: Bederman(1968).

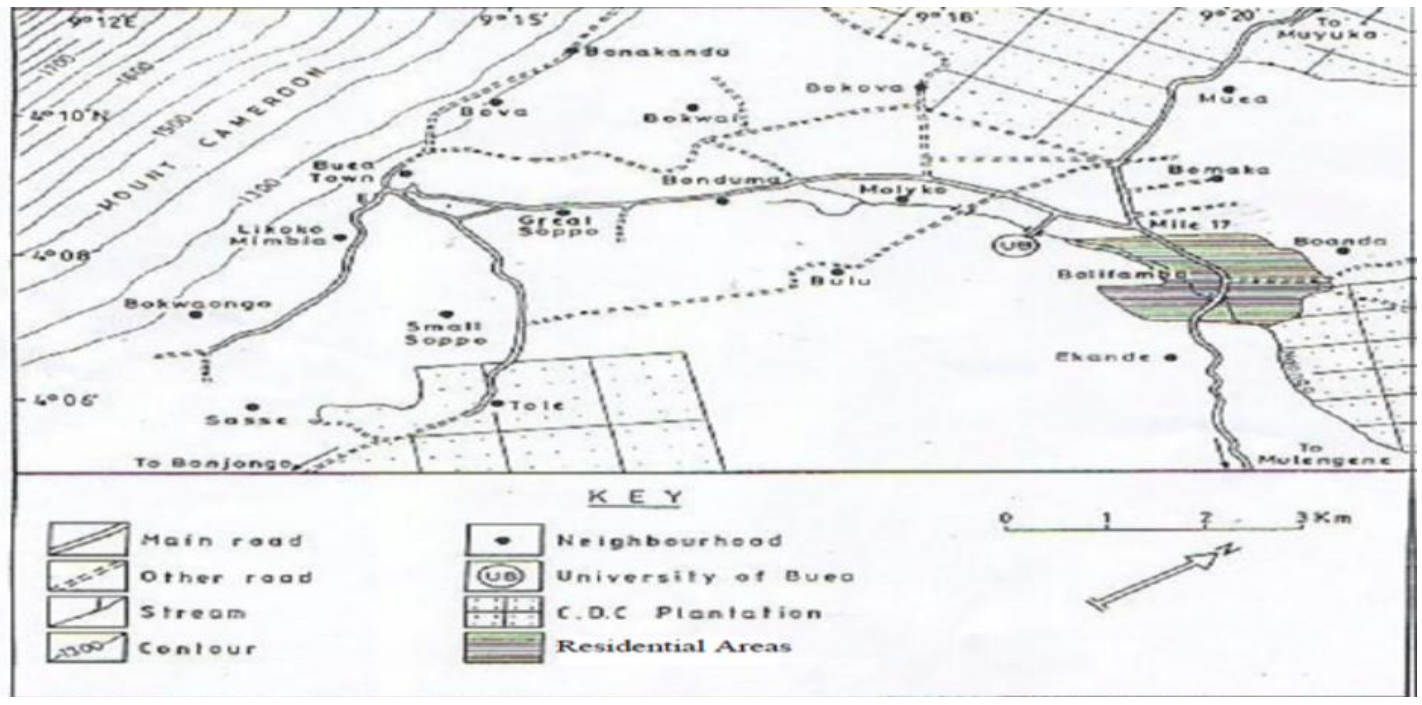

Map5.2. illustrates the situation of Tole in 2013

Source: (CTE annual report sheet, 2014)

\subsection{Methods and Techniques}

\subsubsection{Data Collection}

The researcher employed a qualitative phenomenological research design with purposeful sampling of participants. This approach tries to identify how phenomena are perceived by actors in their natural context. This entails the gathering of in depth information and perceptions through inductive qualitative methods involving interviews, discussions and participant observation (Moustakas, 1994).The collectionof data in this study entailed conducting in-depth interviews with 30 male and female workers drawn from all the sectors in the Tole Tea Estate. Thefieldwork to collect data took place in February-April, 2016 during the first field visit and later in October-November, 2016 during 
the second field visit. Although it was highly demanding due to time constraints, it was the most preferred method due to its flexibility in eliciting detailed information from respondents in their own words, about their social world (Lofland and Lofland, 2006). The researcher also made use of secondary material such as articles, published books, thesis and technical reports.

\subsubsection{Sampling Techniques of the Population}

Purposive sampling was employed to guide in the selection of CTE workers from all the sectors to be used in the study (Yin, 2003). The CTE operates on several plantations located in different parts of the South West, West and North West Regions of the country. The CTE is made up of four tea estates, which include; Ndawara, Tole, Ndu and Djuttitsa. The Tole Tea Estate was selected because it is the only tea estate in the South West Region and the most prominent in the sector dating as far back as 1945.

\subsubsection{Data Analysis}

The study made use of the hermeneutical approach to interpret people's life experiences and meanings with the desire to develop a robust understanding of their world from an epistemological viewpoint, having in mind that knowledge is a social and subjective construct. The results of the study were rich accounts of people's realitiesand how they act within them, buttressed by descriptive statistical data analysis. Interpretation involved the collation of data into conclusions. In addition, the organisation of data entailed the continuous iterative display and assembling of data and information that involved the production of descriptive data in the form of tables, graphs, networks and schematic diagrams. However, the data and information collected were organized into text. However, theoretical frameworks on privatisation and corruption were used to guide this research inquiry and also to summarize data and information during the data analysis and interpretation exercise.

\section{Results}

\subsection{Demographic Characteristics of Respondents}

This study made use of 30 respondents of both sexes. The study asserts that more than $54 \%$ of those interviewed in the Tole tea estate are women owing to their numerical strength in the company (see Table 6.1).The study further affirms that $75 \%$ of the respondents are indigenes from the North West Region, while 19\% come from the South West Region and lees than 3\% from the East and Western Regions Respectively.The main reason for these disproportionate number of workers employed in the CDC owes much to history. The main argument to support this claim is based on the fact that Bakwerians who are indigenes of this area were never interested in plantation work so were considered by the Germans and later the British as very lazy people. The North Westerners are hardworking and come from a region with very few job opportunities. This therefore acted as a push factor for them to migrate to the coastal areas in search of greener pastures. More than $90 \%$ of the respondents have worked with the CDC for more than 10 years as permanent workers at the time of the interview with the majority ranging between 25-55 years of age (see Table 6.2 and 6.3).

Table6.1. Sex and origin of respondents

\begin{tabular}{|l|l|l|l|l|l|}
\hline Category of workers & \multicolumn{2}{|l|}{ Sex/Frequency } & \multicolumn{4}{l|}{ Region of origin/Frequency } \\
\hline Sectors & Male & Female & NW & SW & Other \\
\hline Field workers & 04 & 10 & 10 & 02 & 02 \\
\hline Artisans & 02 & 01 & 03 & 00 & 00 \\
\hline Overseers & 02 & 01 & 02 & 01 & 00 \\
\hline Time keepers & 03 & 02 & 03 & 02 & 00 \\
\hline Checkers & 03 & 02 & 02 & 02 & 01 \\
\hline Sub total & $\mathbf{1 4}$ & $\mathbf{1 6}$ & $\mathbf{2 0}$ & $\mathbf{0 7}$ & $\mathbf{0 3}$ \\
\hline Total & $\mathbf{3 0}$ & $\mathbf{3 0}$ & & \\
\hline
\end{tabular}

Source: Field Survey, 2016

In addition, more than $56 \%$ of the CTE workers are married with children. It should be noted that most of the workers are youths because of the strenuous nature of the job in the plantation. It was also observed that the workers ofthe CTE live at close proximity to the plantations where they work to cut 
Privatisation of the Tole Tea Estate and the Brobon-Finex Saga: A Showcase of Corruption in a State Owned Corporation in Cameroon.

down travelling cost and time. After the privatisation of the TTE, several workers were laid off because they were old and inefficient making it possible for those who were physically very strong and efficient to be retained. It was a strategy used by the CTE management to increase productivity and profits. Though, it was against the terms of the privatisation contract. This therefore accounts for the reason why $80 \%$ of the workers fall between the $25-45$ years age bracket.

Table6.2. Age and marital status of respondents

\begin{tabular}{|l|l|l|}
\hline Age & Number & \multicolumn{1}{|c|}{ Percent } \\
\hline $15-25$ & 02 & 6.66 \\
\hline $25-35$ & 06 & 20 \\
\hline $35-45$ & 12 & 40 \\
\hline $45-55$ & 08 & 26.66 \\
\hline+55 & 02 & 6.66 \\
\hline Total & $\mathbf{3 0}$ & $\mathbf{1 0 0}$ \\
\hline Marital status & 06 & \\
\hline Never Married & 06 & 20 \\
\hline Married & 14 & 46.66 \\
\hline Widow & 04 & 13.33 \\
\hline Widower & 02 & 6.66 \\
\hline Divorced & 02 & 6.66 \\
\hline Free Union & 02 & 6.66 \\
\hline Total & $\mathbf{3 0}$ & $\mathbf{1 0 0}$ \\
\hline
\end{tabular}

Source: Field Survey, 2016

Table6.3. Length of employment and level of education

\begin{tabular}{|l|l|l|}
\hline Length of employment & Number & Percent \\
\hline $0-5$ & 02 & 6.66 \\
\hline $5-15$ & 14 & 46.66 \\
\hline $15-25$ & 11 & 36.66 \\
\hline+25 & 03 & 10 \\
\hline Total & $\mathbf{3 0}$ & $\mathbf{1 0 0}$ \\
\hline Level of education & 08 & 26.66 \\
\hline Illiterate & 16 & 53.33 \\
\hline Primary Education & 06 & 20 \\
\hline Post- primary & $\mathbf{3 0}$ & $\mathbf{1 0 0}$ \\
\hline Total &
\end{tabular}

Source: Field Survey, 2016

\section{Mechanisms of Privatization in Cameroon}

The term privatization designates the transfer of property from the public to the private sector. Under the 1990 ordinance, such transfer may take various forms, which are; total or partial transfers of property either in the form of shares or assets to the private sector.In addition, an important feature of the Cameroonian mechanism of privatization under the 1990 ordinance is that it necessitates transparency in its operation. This serves as assurance to public opinion, which looks at the on-going privatization programme as a threat to national sovereignty. In this light, the ordinance provides guiding principles for the programme. These principles include the prior and proper evaluation of any state owned corporation to be privatized and the necessity for public calls for tenders. This privatization guide ensures that no state owned corporation should be sold at a token rate and that there must have been a prior scrutiny of various tenders to obtain the best offer. This, in other words, guarantees competitiveness between the prospective buyers thus assuring transparency of the operation. Furthermore, article 11 of the decree demands prior evaluation of the public enterprise to be privatized and the need for competition through tenders. But under article 16, these conditions may be waived in favour of a wider participation of civil servants and other state agents. Such derogations as prescribed by law only help to delay the privatization programme through bureaucratic hurdles and consequently promoting the fear of non-transparency in the country (Akonumbo, 2003). 


\subsection{Institutional Framework}

The decree of June 3, 1986 created a commission for the rehabilitation of public enterprises in the country. This commission became the basic organ to manage the privatization programme and was placed under the authority of the secretary general at the presidency of the republic. It was saddled with the responsibility to propose to the Head of State possible solutions pertaining to eradicating and preventing the root causes of the persistent difficulties facing public enterprises in the country. It was made up of two main organs, which are; the inter-ministerial committee and a technical committee. The 1986 decree did not include any issues pertaining to privatization, though this was done later in the March 29, 1995 decree to reorganize the Commission. The Technical Committee was later split into two separate committees by January 3,1997, one in charge of privatization and liquidation and the other on the rehabilitation of public and semi-public enterprises. The new technical committees were established to accomplish a precise mission with the hope of eliminating the inherent problems and delays of the previous organs of the Commission in order to speed up the programme (Republic of Cameroon, 1990).

In addition, the decision-making organ of the commission was the inter-ministerial committee, chaired by the Minister of the Economy and Finance. The committee proposes the annual programme of privatization and carries out all prior studies deemed necessary for the technical preparation of privatization. It evaluates each enterprise to be privatized and advises the inter-ministerial committee on the mode of privatization to be employed. The committee also prepares the file of each enterprise to be privatized, makes tenders and receives offers which are later handed to the inter-ministerial committee. The committee is also charged with the supervision and control of liquidations of public and semi-public enterprises in the country. The institutional framework is a major source of problem to the on-going privatization programme since some of these problems plaguing these organs in charge of the privatization programme had not been sorted out (Republic of Cameroon, 1990a).In addition, article 13(1) state that the committee works in close collaboration with government services involved in the privatization programme. The services are not even mentioned, giving room for unjustified intervention by unauthorized government officials in the privatization process thereby creating confusion. Furthermore, there is also a problem of indecision inherent in some of the texts governing privatization in Cameroon because of the issuing out of so many texts to govern the same matter (Akonumbo, 2003).

\subsection{Legal Framework}

The legal framework governing the privatization programme in the country is congested with too many instruments enacted between 1986 and 1997 making it ambiguous and sloppy. A good example is the February 7, 1996 decree that was characterized by substantive errors, leading to confusion, thereby delaying the privatization process. Furthermore, the August 30, 1990 decree was wrongly quoted in its introductory part. In effect, the 1996 decree sought to modify article 7 of the 1995 decree but instead quoted article 6 . It is surprising how such an error could go unnoticed from the time of the conception of the decree right up to time of signature. This only indicates the carelessness and lack of seriousness with which the authorities in charge are treating the privatization programme. The legal framework governing the institutional framework and the functioning of the privatization programme in Cameroon is choked with several instruments making it ambiguities. There exists also the problem of translating texts which is done poorly (Republic of Cameroon, 1990a).In addition, when a text is conceived in one of the official languages (usually French) it has to be translated to the other. In the process of translating, errors may slip in thereby deforming the sense of a provision. For instance, article 7(3) of January 3, decree is poorly translated from French to English. However, whenever the inter-ministerial committee meets, its secretariat duties shall be performed, as the case may be by the committee that is competent. After the signing of the legal documents pertaining to the transfer of ownership of a corporation under the privatization process based on the analysis of a repealed text which is poorly translated, it becomes very dangerous for the contracting company which might be a multinational company. This is a common characteristic of legal frameworks governing key economic and political institutions in Cameroon. The problem of proliferation of texts is best described as the uncertainty of law (Akonumbo, 2003). 


\subsection{Problems Associated with Privatization in Cameroon}

The launching of the privatization program in Cameroon since the early 1990s has failed to achieve its desired objectives due to a weak financial and economic situation of the country, deficits in institutional structure and poor governance. Furthermore, several states owned enterprises that were listed for privatization have so far not been transferred to the private sector. The main reasons for this lack of progress are associated with legal, strategic, social, and economic factors. However, the legal process of privatization and its institutional setting as provided for by the government are complex and cumbersome and therefore poorly designed for the privatization programme in Cameroon. Furthermore, the sad issue with the privatization programme in the country has to do with the economic situation of enterprises slated for privatization that were not attractive enough to attract potential buyers. The government failed to restructure most of these enterprises before offering them on the market (Kante, 2002). In addition, the privatization negotiations in Cameroon are not transparent. Empirical studies on privatisation in sub-Saharan Africa assert that economic experts find it difficult to define the nature of the privatization programme in Cameroon. They further affirm that the privatization carried out in Cameroon remains ambiguous and fallacious since it does not in any way correspond to the type of restructuring and deregulation that took place in the developed world. Furthermore, although, the August 30, 1990 decree alongside with article 4 of the 1990 Ordinance, clearly states that enterprises to be privatized shall be subjected to an objective evaluation by financial experts, this clause has never been respected (ibid).

Furthermore, the privatization of the Tole tea estate was done in close doors with the assistance of corrupt and unpatriotic Cameroonians who were out to make personal gains at the expense of the state (see figure 7.1). However, though the 1990 ordinance allowed the take-over by nationals of state owned enterprises to be privatized, they were found to lack the necessary financial, technical and managerial abilities to effectively do so. Furthermore, the absence of a well-established financial framework to serve as incentive to Cameroonians to buy over state owned enterprises reveals a major weakness of the programme. Reducing state interference in the management of public enterprises will help it concentrate more on its traditional functions (Konings, 1993a).

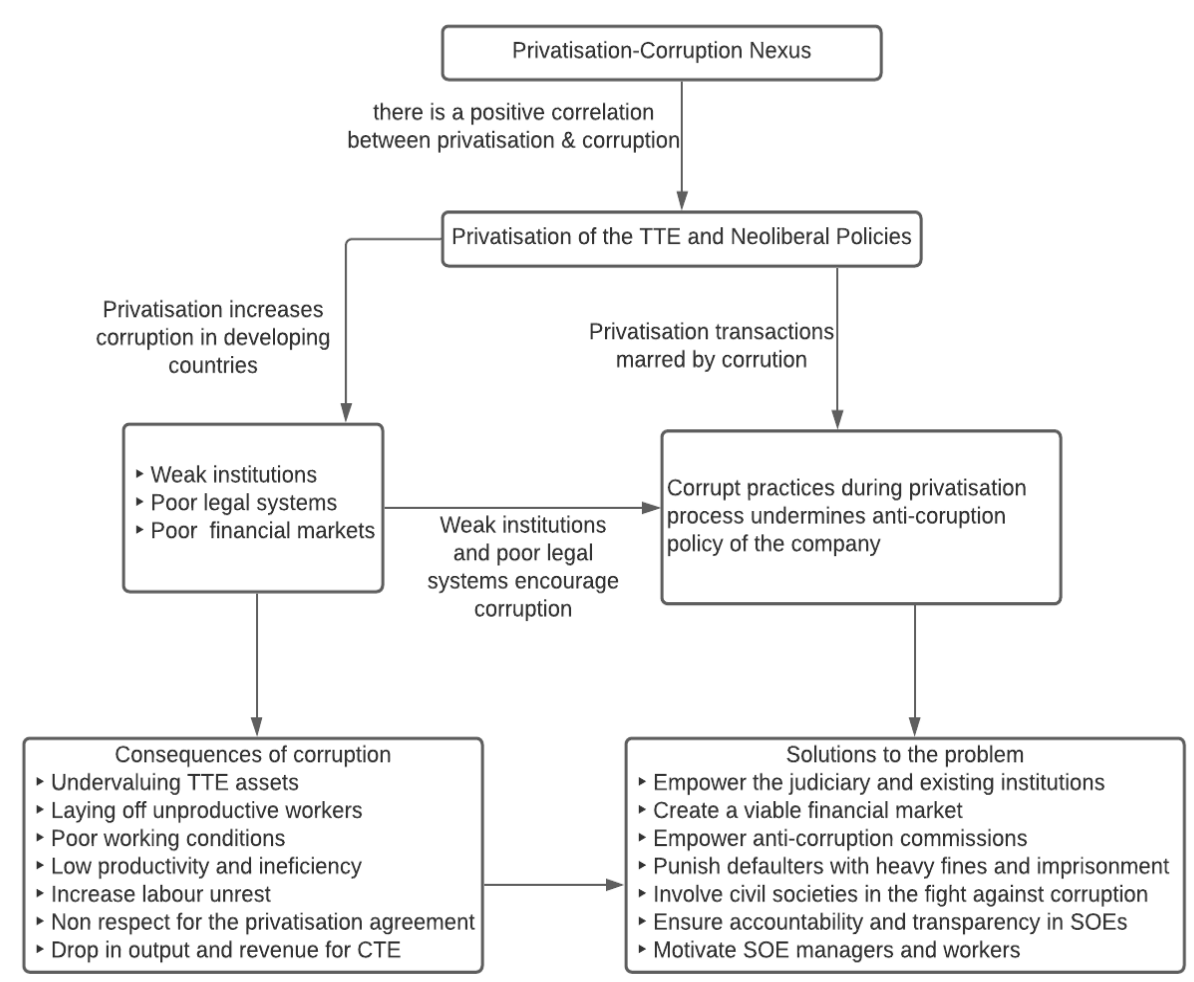

Figure7.1. Privatisation-Corruption Nexus

Source: Field survey, 2016 
Furthermore, responsible management will free the state from fiscal pressures and the burden of issuing out subventions to public enterprises. Privatized public enterprises can now become financially prosperous and competitive in the international market. This goes to explain why the sale of the property of an enterprise may not only be judged from the value of the sale but also from the stand point of investments and development initiatives undertaken by the new enterprise, such as, the creation of jobs. A good example is the case of OCB that was sold for a token rate in 1995, the new structure realized investments worth 4 billion francs within a short period of time. On the other hand, the sale of the Tole Tea Estate was a big loss to the state (Akonumbo, 2003).

\subsection{Privatisation of the Tole Tea Estate}

Attempts by the government to privatize the CDC met with stiff opposition from elites and civil society organizations in the South West and North West Regions. A good example of such a resistance came from the famous Fako Agricultural Workers Union (FAWU) that represents and defends the rights of CDC workers in Fako Division. They argued that the CDC could not be privatized without the consent of FAWU, since workers have made enormous sacrifices during the economic crisis to assist the corporationto recover. In addition, the united Anglophone front tried all what they could to prevent the implementation of the corporation's privatization for some time. However to the dismay of some Anglophones and the Bakweri people in particular, the privatization of the CDC tea estate was announced in October 2002. It became clear that the CDC tea estates had been sold to a South African Consortium, Brobon Finex PTY Ltd. These company (Brobon Finex) was saddled with the responsibility to manage the tea sector in Tole under the name of Cameroon Tea Estates (CTE) (Konings, 2003).

The privatization agreement that was reached between the Cameroonian government and Brobon Finex was based on the following terms: the government was to hand over $65 \%$ of its shares to Brobon Finex which, in turn, would sell 5\% of its shares to its personnel. In addition, Brobon Finex was also to increase the area allocated for the cultivation of tea at Tole from 1,500 to 3,000 hectares in fifteen years and invest about FCFA 8 Billion over ten years. It would also reimburse all the loans owed by the CDC tea sector which was estimated at about 1.1 billion Francs CFA. In addition, CTE also agreed not to lay off workers but will instead improve existing health, educational and accommodation facilities, and will continue to buy produce from local contract farmers. Lastly in accordance with government's privatization policy, land would be excluded from the transaction (ibid).However, the BLCC expressed dissatisfaction at the sale of the CDC tea estates without any consultation and compensation of the landowners, despite previous meetings between the committee and the government on how the privatization should be carried out. The Southern Cameroons National Council (SCNC), claimed that the Francophone-dominated state had no right to privatize, sell or transfer CDC tea estates located within her territorial boundaries to South Africans (ibid). Furthermore, in March 2000, the trade union warned the government that the 1992 Labour Code stipulated that workers should be consulted in the event of privatization as to whether they would prefer to be paid off before negotiating new contracts with the CTE. The privatization of the CDC tea estates became a national scandal when it was made known by some media outlets that some unpatriotic politicians were going to benefit at the expense of the public treasury and the native landowners (ibid).

The privatization of the tea sector was masterminded by John Niba Ngu, a former CDC GM and Minister of Agriculture, who was a close friend of President Biya. He employed his technical knowledge and connections within the regime in power to design the fake privatization of the CDC tea estates. Though, economic and financial experts had estimated the value of the three tea estates at about FCFA 10 billion, John Ngu and his collaborators finally sold the tea estates at FCFA 1.5 billion. In addition, to compensate the GM for his loyal services to the CTE, the Board of Brobon Finex appointed John Ngu as general manager on a monthly salary and benefits of about FCFA 4 million. He was also allocated $5 \%$ of the CTE's share capital, although this was later contested by the Board of Brobon Finex. There were also growing doubts about Brobon Finex's takeover when it became clear that the real owner of the CTE was Alhadji Baba Danpullo, who was using Brobon Finex as a shield (ibid). However, although he was not a signatory to the agreement between the government and Brobon Finex, he paid the money for the takeover of the CDC tea estates to the public treasurer and has since then been fully engaged in other financial transactions on behalf of the CTE. Investigations 
carried out by the BLCC a year later in South Africa found that Brobon Finex existed in name only and had no office premises. Its chairman, Derrick Garvie, was indeed known in South African business circles but not in connection with Brobon Finex. These were enough evidence to justify the fact that Brobon Finex was merely a straw company (ibid).

In January 2003, the BLCC threatened to sue Brobon Finex in South Africa for trespassing on Bakweri property without the prior consent of its owners and also for the government to revoke the controversial privatization of the CDC tea estates and arrange meaningful dialogue with the BLCC with a view to achieve an equitable resolution of the Bakweri land problem. In the face of such glaring evidence of financial malpractices, President Biya gave orders for the Prime Minister to investigate the matter. The outcome of these investigations has never been made public but it is widely believed that Danpullo have been using his political network to help settle the matter and have also given bribe to the investigators. Furthermore, this controversial privatization scheme has had negative consequences on the Tole tea workers whose living and working conditions have been badly affected by the economic recession prior to privatization. Plantation workers in the Tole tea estate have now resorted tolabour militancy as a medium to express their dissatisfaction with the prevailing situation going on in the CTE (Konings, 2003).

\subsection{Brobon-Finex Saga}

The Bakweri Land Claims Committee (BLCC) carried out an extensive investigation into the identity of Brobon-Finex since October 2002 that provided vivid information about the allegations being made in Cameroon that this South African consortium that purchased the Tea estates of the Cameroon Development Corporation is a dummy Corporation set up by unpatriotic Cameroonian politicians with the assistance of South African accomplices to defraud the Cameroonian people of their natural resources. Furthermore, shortly after the sale agreement was completed between the Government of Cameroon and Brobon Finex, the BLCC decided to contact the South African company to draw its attention to the fact that the sale agreement had failed to address the issue of indigenous land rights, which will culminate to opening up a lawsuit in South Africa where the issue of alienated ancestral land rights was a sensitive issue. In the course of this, the BLCC immediately ran into an unexpected roadblock since Brobon-Finex was untraceable and there was no information about the existence of this consortium even from the South African Ministry of Trade and Industry (Konings, 2003a).

In addition, to be sure that the investigations carried out were valid, the BLCC then solicited the services of Dunn and Bradstreet a leading provider of business information to confirm the mounting suspicion that Brobon-Finex was not real. They found out that there were no information for BrobonFinex on their database and also the fact that the company could not be found on the South African Registry of companies. On the other hand a similar search on the database of the French-based Transnational Corporations Observatory, which has a huge inventory of South African companies, yielded no information about Brobon-Finex, though the company was added to the observatory's database in November 2002 - after the purchase of the CDC tea estates. However, there is increasing evidence to justify the allegations that Brobon-Finex had spearheaded fraud, money laundering and asset stripping. The CDC deal is concrete evidence of Cameroonians setting up a dummy corporation in a foreign country with the aim of defrauding their fatherland (ibid).In spite of the mounting evidence that Brobon Finex is a dummy corporation, the BLCC was willing to give Brobon Finex and its associates in Cameroon a fair hearing. The rhetorical question here is whether the government was an active participant in this deal or did the government in its desperation to meet the deadlines of the IMF and WB conditionality's simply turn a blind eye to the lapses of the Brobon-Finex File? However, the BLCC holds that the deal between Brobon-Finex and Cameroon Tea Estates should be rescinded forthwith and a new transparent privatization process that adheres to the rule of law and taking into consideration the rights of all stakeholders, while placing national interests above any other interest be launched by the government to ensure fairness and equity (Konings, 2003a)

\subsection{Privatization and Labour Militancy in the Tole Tea Estate}

It is very clear that civil society organizations in the South West Region were excluded from the decision-making process because of their stiff resistance to the negative effects of the neoliberal privatization scheme imposed on the CDC as conditionality's for loans. Academics and ethno- 
regional movements have strongly denounced the sale of national assets to western multinationals and to nationals who are closeto the regime in power (Konings, 2007a). The privatizations of strategic public enterprises in Cameroon have always been associated with violent protest from the workers due to massive layoffs without compensation. The privatization of the CDC tea estates generated persistent regional protest and protracted strikes by workers. The announced privatization of the CDC tea estates in October 2002 was fiercely opposed by Anglophone and other ethno-regional organizations. There have been a growing sense of militancy by the Tole and Ndu tea workers due to a dramatic deterioration in their working and living conditions after the privatization of the Tole tea estates (Konings 1993a; 1995).

The Anglophone press were the first to criticize the announced privatization of the CDC tea estates and later informed the Anglophone population of the privatization issues at stake. The united Anglophone front was able to prevent the implementation of the corporation's privatization programme for some time. However, to the dismay of many Anglophones and the Bakweri in particular, it was announced in October 2002 that the CDC tea estates had been sold to a South African consortium, Brobon Finex PTY Ltd, that will be saddled with the responsibility to run the tea sector, including the Tole Tea Estate in Tole under the name of Cameroon Tea Estates (ibid).The privatization agreement between the Cameroonian government and Brobon-Finex was based on the fact that plantation workers should not be lay off, improve existing living conditions and make health cost affordable to workers. The BLCC expressed dismay at the sale of the CDC tea estates without consultation and compensation being allocated to the present landowners in spite of an agreement that was reached between the government and BLCC committee in the South West region (Konings, 1995). In March 2000, the FAWU trade union warned the government that the 1992 Labour Code stipulated that workers should be consulted in the event of privatization as to whether they would prefer to be paid off before negotiating new contracts with the new employer. However, due to the growing labour unrest in the Tole Tea Estate the CDC management hadn't the courage to inform the Tole Tea estate workers of the planned privatization of these tea estates. The workers came to learn of it through the media (ibid).In addition, Tole tea workers were filled with a lot of dismay when Alhadji Danpullo, decided in November 2002 to transfer 23 managerial staff from his business enterprises in Douala to CTE, because he wanted workers who would be loyal to him. His decision created serious problems amongst plantation workers in the Tole tea estate. These newly appointed managers were Francophone and had difficulty communicating in the English language with the other managers and workers who were Anglophone (ibid).

In addition, as a result of the rising tension between the management and workers, there was a strike action organized by the workers from 29 December 2002 to 4 January 2003 at the Tole tea estate. Their reasons for carrying out this strike action were as follows; poor working and living conditions, environmental pollution due to poor waste disposal, unpaid salaries and low incentives, unpaid socialsecurity moneyto the National Social Security fund for many years and poor medical facilities. In addition, to make matters worse, on January 4, 2003, the CTE's GM, Niba Ngu, was suddenly dismissed andreplaced by his Francophone Deputy GM, Mahamat Alamine Mey. Thisfollowed a serious strike action being masterminded by workers who hail from the North West Region who were sympathetic to the former GM.A few days later, the new CTE GM, Alamine Mey signed a protocol agreement with the president of FAWU reassuring workers that all their acquired rights would be honoured (Konings, 1993a; 1995a).A few days later, the CTE management carried out a controversial reorganization programme in December 2003 that went against the 1992 labour code. The government did nothing to address the situation since Alhadji Danpullo had cordial relations with the regime in power. The reorganization programme had negative consequences on the welfare of plantation workers of the Tole tea estate, that were, a $50 \%$ slash in workers' salaries and the withdrawal of any remaining allowances allocated to field workers. The TTE workers reacted negatively to this dramatic cut in their income by resorting to protracted strike action that began in January 2004. The CTE management used this illegal strike action as a pretext to dismiss 268 workers without paying their benefits and immediately embarked on a programme to recruit new workers from outside the Anglophone Region (Konings, 1993a). 
However, workers growing sense of awareness for a common goal to fight for their rights became a source of solidarity. This manifested itself clearly in 2006 when they organized a protracted strike action that lasted for many months, have been described by some communication analysts in the country as the longest in our labour history, that paralyzed all TTE activities for almost an entire year (see Photo 7.1 and 7.2 below). The new management of the TTEhave failed to respect the terms of the privatisation agreement. In February 2006, 736 workers were dismissed without compensation and this led to a strike action that lasted till July 2006. Workers that were involved in the strike action were arrested and the poor handling of the crisis by the police angered the workers, to the extent that female workers were forced to strip naked at the police station where their arrested colleagues were kept in a bid to precipitate the release of their colleagues.

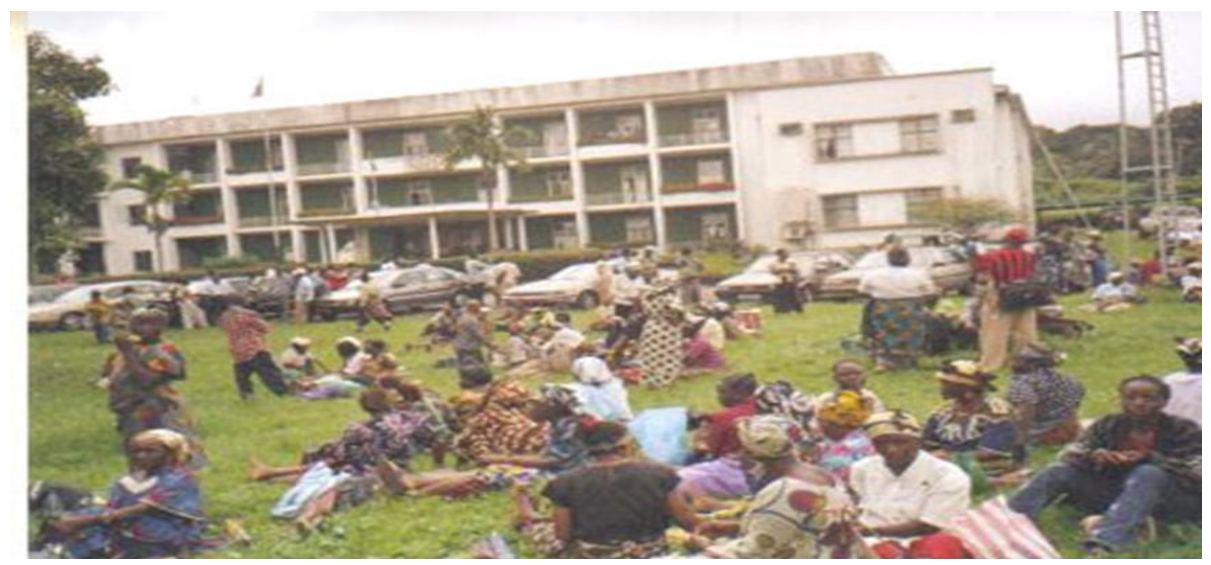

Photo7.1. CTE workers besiege CDC head Office

Source: Cameroon Post Line (2006)

Photo 7.1 showing striking CTE Tole tea workers in front of the CDC headquarters in Bota-Limbe clamouring for the payment of their retirement benefits in 2006.

Plantation workers of the Tole tea estate had been exposed to untold hardships following privatization and were therefore unable to send their children to school. However, to address this deadlock, the Minister of Labour and Social Security organized a crisis meeting in Buea in April, 2006, but in spite of heated debates, he failed to persuade workers' representatives to accept the CTE management's initial offer of FCFA 14.9 million.

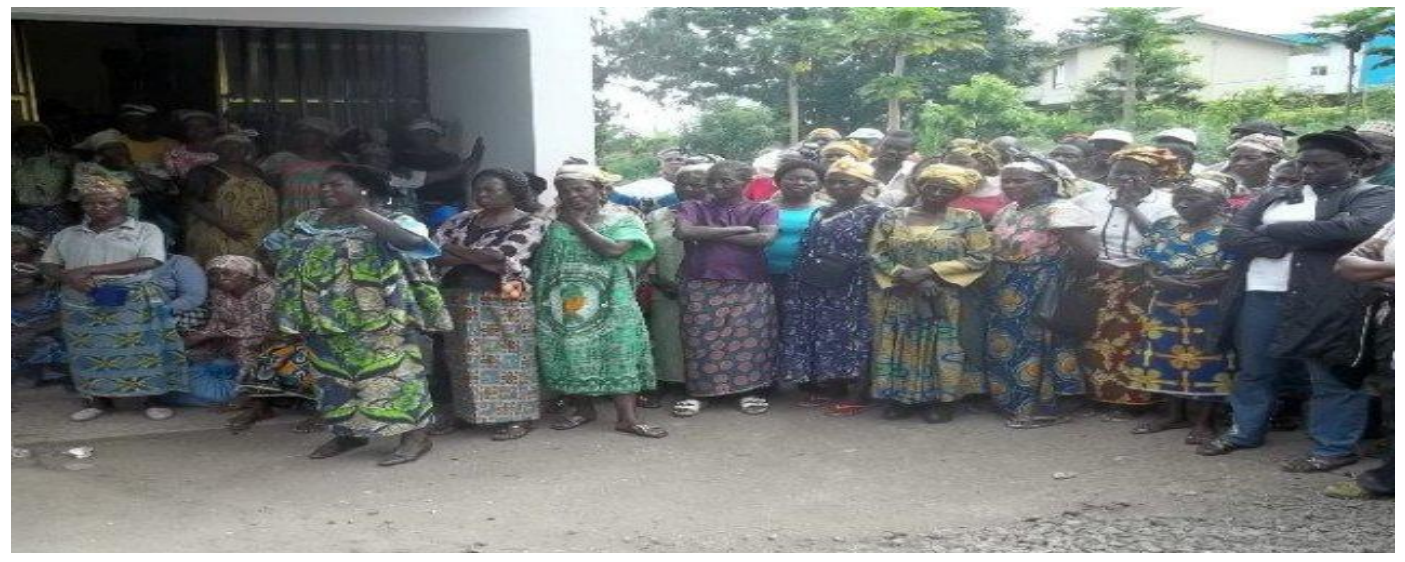

Photo7.2. Helpless Tole tea workers demanding their rights

Source: Cameroon Post Line (2006)

Photo 7.2 is a display of retired CTE workers striking in front of the Regional Delegation for Labour and Social Security Buea.

However in the end, he reached a compromise with both parties agreeing that all the accrued benefits should be paid out within three months (Konings, 1993a). On 26 of July, 2006, about 800 men, women and children from the Tole Tea Estate occupied the CDC's Head Office, requesting the sum of FCFA 2.3 billion in accrued benefits (see Photo 7.1). 


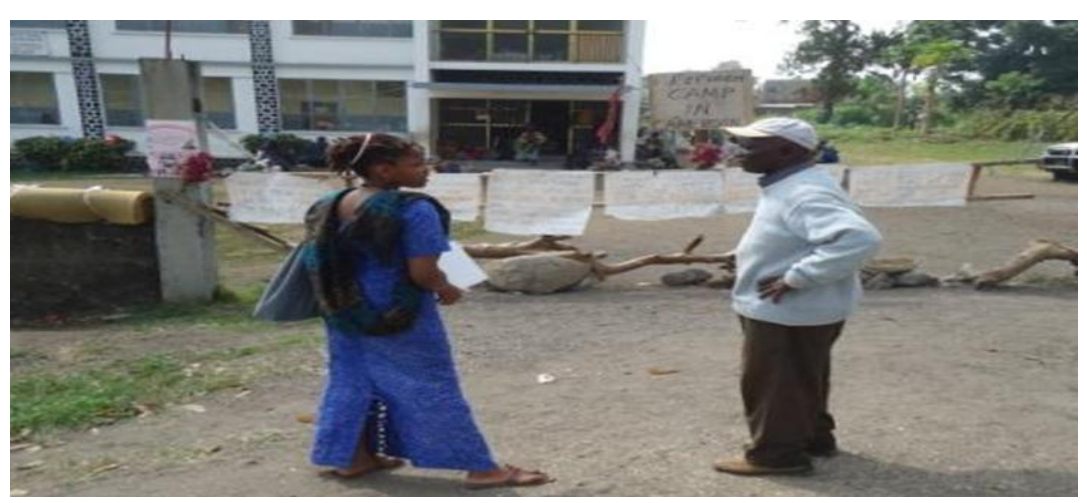

Photo7.3. CTE workers block the entrance to the labour office in Buea

Source: Cameroon Post Line (2006)

Photo 7.3 illustrates a barrier made up of sticks and stones that has been used to block the entrance of the Regional Delegation for Labour and Social Security in Buea.

However, although the regional governor and the CDC General Manager ordered them to leave, the workers resolved to stay until a lasting solution to their problems had been found. Furthermore, the workers had to call off the strike action due to the peaceful intervention of President Biya persuading the workers to call off their protest action on the $4^{\text {th }}$ of August, and open room for dialogue between the workers and the CTE management in the presence of the Prime Minister Ephraim Inoni as the chief mediator. The Prime Minister had to set up an ad-hoc committee composed of government, CTE management and workers' representatives that were presided over by the Minister of Labour and Social Security in order to ensure the prompt payment of accrued dues owed the workers. This payment was to take place after two weeks but was later postponed (see Photo 7.3 above) (Konings, 1993a). However, it was only after pressure through persistent labour unrest that the regional administration announced it would make payments on 30 August 2006, without failure. A month later, all the workers who had been paid off forcibly left the Tole Tea Estate. Those who still wanted to work on the estate were required by the CTE management to reapply as new workers and engage in new terms of contract (ibid).

\section{DISCUSSION}

The privatisation of the Tole tea estate was marred by corruption creating several problems for the government, CTE and the workers. The corrupt privatisation negotiation of the TTE was masterminded by the former GM of the CDC John Niba Ngu with the support of top government officials and some prominent elites from the Anglophone region. The former GM did everything he could to deprive valuators of vital informationpertaining to the company and also connived with some workers to do same, making it difficult for the valuators to come out with a robustvalue of the company assets in monetary termsthereby leading to the undervaluing of the assets of the corporation. The TTE was sold at a giveaway price to Brobon-Finex Plc. a fake South African company owned by Alhadji Danpullo. In addition, the privatisation negotiations were also not transparent since key stakeholders like the workers trade union, BLCC and South West elites were not invited to attend the deliberations. The absence of the workers trade union from the negotiating table meant that the plight of the workers was never taken in consideration and this goes to justify why a few months later the CTE management had to put in place drastic austerity measures in a bid to increase production and profits, such as;an increase in working hours, a drastic reduction in fringe benefits and laying-off unproductive workers without immediate compensation. The mounting discontent amongst workers at the time fuelled tension giving them a leeway to organise strike actions in a bid to clamour for their rights. Persistent labour strikes have led to a drop in outputand revenue for the company. However, though the government and the CTE management have tried to solve some of these problems, much still has to be done to restore production to its previous level. It should be noted that the CTE has failed on her part to respect all the terms of the privatisation agreement and the government has done nothing to make the terms bidding since top government officials are always bribed by the owners of CTE to stay silent at the detriment of the state and CTE workers who are living in abject poverty and misery. 


\section{CONCLUSION}

The rapid growth of corruption in developing countries in recent decades owes much to the rapid privatisation taking place that wasmasterminded by the IMF and World Bank. State owned enterprises are vulnerable to corruption due to their closeness to governments in power, influential politicians and public officials who take decisions in key sectors of the economy. An OECD report clearly affirms that $81 \%$ of bribery cases were promised, offered or given to SOE officials. Empirical studies on corruption in developing countries assert that state owned enterprises are plagued by poor governance, weak management systems and inefficiency, thereby making corruption inevitable. The privatisation of the Tole tea estate was marred by corruption due to the absence of well-established institutions and legal framework, contradictory regulations, bureaucratic bottle necks and the absence of a viable financial market in the country. This dilemma can also be associated to selfishness and unpatriotic spirit of some influential politicians from the Anglophone region and the former General Manager of this state owned corporation. It should be noted that corruption has become a normal way of life in Cameroon. Transparency International perception index ranked Cameroon as one of the most corrupt country in the world in 1989 and 1999, respectively. The privatisation of the Tole tea estate was a total blunder on the part of the government. A preliminary valuation of the company's assets before privatisation puts the market value of the company at about 10 billion CFA Franc, though it was finally sold at a giveaway price of about 1.5 billion, CFA Franc by corrupt and unpatriotic Cameroonians for their selfish gains. The manner in which the TTE was privatised is a violation of the 1990 ordinance which states that no state owned enterprise should be sold below its market price; it is therefore an offence punishable by the Law. However, all those who were involved were never made to pay for their crimes even though the topic was top on the agenda in all the radio and newspapers at the time. The privatisation of the TTE without the consent of the workers trade union and the Bakweri elites have had negative consequences on the livelihood of plantation workers, who have resorted to strike action to make their voices heard with devastating effects on the output and revenue of the CTE. In a bid to fight against corruption in SOEs, all stakeholders (state, civil society, managers and entrepreneurs) need to put in place robust mechanisms for SOEs to operate at high standards of integrity, transparency and accountability. They should monitor and hold SOE managers to account in order to achieve these standards. The OECD guideline and Transparency International's ten anti-corruption principles stand out as the best standards that should be implemented by SOE managers in Cameroon with the support of the government, civil societies and international organisations.

\section{ABBREVIATIONS}

BLCC: Bakweri Land Claim Committee.CTE: Cameroon Tea Estates.

CDC: Cameroon Development Corporation.FAWU: Fako Agricultural Workers Union.

GM: General Manager.TTE: Tole Tea Estates.

Plc.: Public Limited Company.

\section{CONFLICT OF INTERESTS}

The author has not declared any conflict of interests.

\section{ACKNOWLEDGEMENTS}

I am deeply indebted to my supervisor, ProfessorMoïseMoupou of the University of Yaounde I, whose intellectual guidance and wide research experience ensured completion of this study.Special thanks and gratitude also go to my Ph.D. colleagues of the University of Yaoundé I who assisted me during the data analysis and proof reading of this article.

\section{RESEARCH INTERESTS}

Livelihood and coping strategies, Environmental governance, corporate social responsibility, industrial restructuring, carceral geography, food security, land degradation, land cover change, climate variability and land governance. I work as a civil servantin the Ministry of Secondary Education and also the CEO of CAMPROSUDEV-Cameroon. 


\section{REFERENCES}

[1] Jeffrey R. Boles, (2014): The Two Faces of Bribery: International Corruption Pathways Meet Conflicting Legislative Regimes, 35 MICH. J. INT'L L. 673Available at: https://repository.law.umich.edu/mjil/vol35 /iss $4 / 1$

[2] OCDE (2015): OECD Guidelines on Corporate Governance of State-Owned Enterprises. OCDE Publishing. Paris, France.

[3] KONINGS, P. (2003): Privatisation and Ethno-Regional Protest in Cameroon. Africa Spectrum, 38(1), 5-26.

[4] Rose-Ackerman, Susan (2014): Corruption and Conflicts of Interest. In: Jean-Bernard Auby, Emmanuel Breen and Thomas Perroud, eds. Corruption and Conflicts of Interest: A Comparative Law Approach, Cheltenham, UK: Edward Elgar.

[5] Hellmann, Joel, and Daniel Kaufmann. (2001): "Confronting the Challenge of State Capture inTransition Economies." Finance and Development: 31-35.

[6] Bennell, Paul. (1997):"Privatization in Sub-Saharan Africa: Progress and Prospects during the 1990s." World Development 25(I): 1785-1803.

[7] Tangri, Roger, and Andrew Mwenda. (2001): "Corruption and Cronyism in Uganda's Privatization in the 1990s." African Affairs 100 (398): 117-33.

[8] Svensson, Jakob. (2005): "Eight Questions about Corruption.” Journal of Economic Perspectives 19(3): 19-42.

[9] Klitgard, Robert E; (1988): Controlling Corruption (Berkeley: University of California Press).

[10] Groenendijk, Nico (1997): A principal-agent model of corruption. Crime, Law and Social Change, vol. 27 , issue 3-4 (May), pp. 207-229.

[11] Appolloni, Andrea, and Jean Marie Mushagalusa Nshombo (2014):Public procurement and corruption in Africa: a literature review. In: Francesco Decarolis and Marco Fray, eds. Public Procurement's Place in the World: The Charge towards Sustainability and Innovation, Palgrave McMillan, Basingstoke.

[12] Bechem, E. E. (2018): Corruption in Cameroon: Public Perception on the Role and Effectiveness of the Different Anti-Corruption Agencies. Review of Public Administration and management.

[13] Transparency International. (1998 \& 1999): Corruption Perception Index (CPI).

[14] BEDERMAN, S.H. (1968): The Cameroon Development Corporation: Partner in national growth, Victoria-Bota: $C D C$.

[15] Akara, D. T., (2006): "Plantation Agriculture in the Former British Southern Cameroons: Female Labour on the Tole Tea Estate, 1958 - 2002,” M.A. Thesis, University of Buea.

[16] Cameroon Tea Estates (2014): Annual Report Sheet.

[17] MOUSTAKAS, C. (1994): Phenomenological research methods.London, Sage

[18] LOFLAND, J., \& LOFLAND L. H. (2006): Analysing social settings: a guide to qualitative observation and analysis, Belmont, CA: Wadsworth/Thomson Learning.

[19] YIN, K. R. (2003): “Case Study Research: Design and Methods”. Sage Publications Inc.,

[20] AKONUMBO, A.N. (2003): The legal Aspects of Privatization in Cameroon. The Experience and the Lessons. Verfassung und Recht in Übersee / Law and Politics in Africa, Asia and Latin America, Vol. 36, No. 1 (1. Quartal 2003), pp. 75-10

[21] REPUBLIC OF CAMEROON (1990): "Projet" Dimension sociales de L'adjustement Structurel "Présentation a 'la Conference des Bailleurs de Fonds. Paris.

[22] REPUBLIC OF CAMEROON (1990a): Les Privatisations au Cameroun - Les Objectifs, Ministère de l'Economie et des Finances, Commission Technique De Privatisation et Des Liquidations, Government of Cameroon, Yaoundé.Retrieved: October 2013 from http://www.gcnet.cm/CITE/privatisations/page_accu eil.htm.

[23] KANTE, P.N. (2002): Les contraintes de la privatisation des entreprises publiques et parapubliques au Cameroun. Revue Internationale de droit économique 2002/4 (t. XVI, 4)

[24] KONINGS, P. (1993a): Labour resistance in Cameroon: Managerial strategies and labour resistance in the agro-industrial plantations of the Cameroon Development Corporation, London: James Currey.

[25] KONINGS, P. (2003): Privatisation and Ethno-Regional Protest in Cameroon. Africa Spectrum, 38(1), 5-26

[26] KONINGS, P. (2003a): 'Chieftaincy and Privatization in Anglophone Cameroon'. In: W. van Binsbergen, ed., The dynamics of power and the rule of law: Essays on Africa and beyond, Münster: LIT Verlag, 79-99.

[27] KONINGS, P. (2007a), 'The neoliberalising African state and private capital accumulation: The case of Cameroon'. In: A.E. Fernández Jilberto \& B. Hogenboom, eds, Big business and economic development: 
Privatisation of the Tole Tea Estate and the Brobon-Finex Saga: A Showcase of Corruption in a State Owned Corporation in Cameroon.

Conglomerates and economic groups in developing countries and transition economies under globalisation, London/New York: Routledge.

[28] KONINGS, P. (1993a): Labour resistance in Cameroon: Managerial strategies and labour resistance in the agro-industrial plantations of the Cameroon Development Corporation, London: James Currey.

[29] KONINGS, P. (1995): 'Plantation labour and economic crisis in Cameroon', in: Development and Change, vol.26, no.3, pp. 525-549

[30] KONINGS, P. (1995a): Gender and class in the tea estates of Cameroon. Aldershot: Avebury, African Studies Centre Leiden Research Series no. 5.

[31] CAMEROON POST LINE (2006): Striking CDC Workers. Retrieved 2019, Jan. 12 from https://cameroo npostline.com/striking-former-tole-tea-workers/Accesssed

\section{AUTHOR'S BIOGRAPHY}

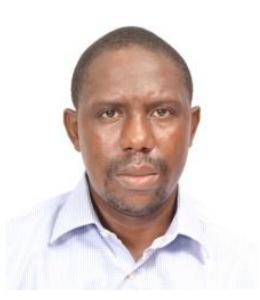

Clovis Ebot Obale, Ph.D. Candidate, with an M.Sc. in Human Geography from the University of Eastern Finland, an M.A in International Relations from the International Relations Institute of Cameroon (IRIC), a Postgraduate Diploma in Education from the University of Yaounde I alongside a B.sc in Geography (Hons) from the University of Buea.

Citation: Clovis Ebot Obale. "Privatisation of the Tole Tea Estate and the Brobon-Finex Saga: A Showcase of Corruption in a State Owned Corporation in Cameroon. " International Journal of Research in Geography. vol 6, no. 2, 2020, pp. 27-42 doi: http://dx.doi.org/10.20431/2454-8685.0602004.

Copyright: (C) 2020 Authors. This is an open-access article distributed under the terms of the Creative Commons Attribution License, which permits unrestricted use, distribution, and reproduction in any medium, provided the original author and source are credited. 